\title{
A review of the role of grazing management on the growth and performance of white clover cultivars in lowland New Zealand pastures
}

\author{
J.L. BROCK and M.J.M. HAY \\ AgResearch Grasslands, Private Bag 11008, Palmerston North
}

\begin{abstract}
The current state of knowledge of white clover clonal growth processes and defoliation management is reviewed, and general recommendations on grazing principals made. Defoliation frequency determines herbage productivity through the manipulation of size/ density compensation between plant organ size (leaves) and numbers of growth units (growing point density). Hence large-leaved cultivars (Pitau, Kopu, Aran) are generally more productive under rotational grazing, whereas small-leaved cultivars are better suited to frequently grazed or set stocked conditions (Tahora, Prestige). The key to persistence is high growing point density, and the development of large-leaved densely branched cultivars should have superior performance over a wider range of grazing managements (Demand, Sustain).

Grasses (perennial ryegrass, cocksfoot and tall fescue) grow by similar clonal processes to white clover and react in a similar manner to grazing management. Maintenance of pasture density (growing points/tillers) is crucial to persistence and is best achieved by rapid rotations or set stocking during spring/early summer. This provides protection against drought, and allows better exploitation of the genetic potential of species and cultivars through alternative grazing strategies over the remainder of the year.
\end{abstract}

Keywords: clonal growth, cultivars, grazing management, morphology, populations, rotational grazing, seasonal growth patterns, set stocking, Trifolium repens L., white clover

\section{The role of white clover}

The main biological role of white clover in grazed, mixed pasture, is to build and maintain soil fertility. This is accomplished by fixation of atmospheric nitrogen through a symbiosis with Rhizobium bacteria, thus reducing reliance on fertiliser $\mathrm{N}$ and maintaining an efficient, low-cost farming system. That white clover also produces superior quality herbage for high livestock performance adds to its desirability. These attributes are not necessarily complementary and their expression will depend on the conditions prevailing in any particular situation, and has been the subject of intensive research in New Zealand (Brock et al. 1989)

\section{Nitrogen fixation}

Plant growth is dependent on nutrient supply, of which nitrogen in the readily available mineral form released through mineralisation of soil organic matter, is usually in the shortest supply and therefore the most important. White clover, having an alternative guaranteed source, is able to grow in situations of low $\mathrm{N}$ supply provided adequate supplies of other nutrients are available. However, N-fixation is not obligatory, and white clover will use mineral $\mathrm{N}$ first if available, and $\mathrm{N}$-fixation second to make up any short-fall in $\mathrm{N}$ demand for growth ie. $\mathrm{N}$-fixation operates predominantly under conditions of $\mathrm{N}$ deficiency within the plant (Hoglund \& Brock 1987).

Historically, New Zealand livestock farming systems have capitalised on this attribute of white clover. Encouraging white clover growth by supplying the necessary macro-nutrients phosphorus and sulphur as superphosphate fertiliser, plus micro-nutrients molybdenum and copper as required, results in an accumulation of $\mathrm{N}$ that is transferred through the grazing process to the soil organic matter. As soil fertility and nutrient supply increase, the more competitive grasses dominate and white clover growth declines. In this way, building soil fertility through fixed $\mathrm{N}$ inputs becomes selfregulating, and eventually an equilibrium is reached where $\mathrm{N}$ inputs via white clover are needed only to balance $\mathrm{N}$ losses from the system (Ball 1982; Field \& Ball 1982). This equilibrium level is far below that which would sustain maximum white clover production. Fortunately, the aggregated pattern of high $\mathrm{N}$ return in urine patches by the grazing animal, results in high losses through ammonia volatilisation and nitrate leaching (Ball 1982), creating a mosaic of patches of variable $\mathrm{N}$ status allowing white clover to maintain itself.

\section{Herbage production}

White clover herbage is superior to grass as a food source for animal production (Ulyatt 1985), but because of its open stoloniferous habit and poorer competitive ability for nutrients, it occupies a secondary position in 
mixed pastures dominated by more competitive grasses, with its upper limit of production regulated by, and inversely related to, soil fertility. It is clear that a goal of high total pasture productivity with high white clover content is probably unrealistic, even with the best of management inputs.

\section{Growth of white clover in pastures}

\section{Growth habit}

White clover is a guerilla-type species, extending vegetatively into favourable niches by lateral extension of a system of branching stolons through indeterminate growth of the apical growing point. Normally, growth at the apex is balanced by periodic death of older basal stolon made redundant by the new growth (Kershaw 1959; Hollowell 1966), releasing the branches to form smaller new plants of varying size and branching complexity. Such fragmentation produces a population of plants, which, while in continual flux between branching orders, maintains a relative stability in distribution among the categories of branching complexity on average for most of the year, except spring (Brock et al. 1988).

\section{Seasonal growth pattern}

The growth pattern is normally as follows. During the winter when growth is slow, a large proportion of stolon is buried by earthworm activity and animal treading in soft soil (Hay et al. 1987). In late winter-early spring with the commencement of new growth, many new nodal roots are formed, and as the growing points regain the soil surface in the warming spring environment, large proportions of old roots and stolon from the previous season die and decay rapidly (Hay et al. 1983). This creates a temporary imbalance in distribution of the population among categories of branching complexity, with the proportion of small plants increasing in mid-spring (October) (Brock et al. 1988), many of which die, as often there is no corresponding increase in plant numbers (Hay et al. 1989). However, surviving plants then grow quickly to return the population to its original more stable distribution in the summer (Brock et al. 1988). Depending on the prevailing weather pattern, the fragmentation period can be displaced or not occur at all. Nevertheless, fluctuations in fragmentation rates occur at some time in most years, and the resultant population of small plants can be susceptible should some additional resource limitation also occur while plants are small. The change in size of plants comprising the white clover population is not easily discernible as the growing point density is often not significantly affected, and consequently there is little effect on herbage production. As this change occurs when pasture growth rates are usually very high, any lack of control of grass growth, by use of over-long rotations, or the injudicious use of fertiliser $\mathrm{N}$, can result in competitive effects that lead to death of significant numbers of white clover plants.

\section{Effects of defoliation}

In general, defoliation system has not been shown to have large effects on the clonal growth processes described. Grazing management studies indicate that while fluctuations in decay of old stolon and plant fragmentation may be greater under rotational grazing than set stocking, the seasonal pattern of growth remains similar. On average, white clover plants are relatively small and simple in structure comprising 5-6 stolons and 8-9 leaves (Brock et al. 1988).

The interaction of defoliation frequency and severity has large effects on the size of individual plant organs (DW, leaf area, internode length and diameter), and the survival rates of individual growth units (stolons and tillers). Infrequent, severe defoliation as practised under rotational grazing, while allowing development of larger organs (leaves, tillers, etc.), also results in the death or disappearance of many new growth units under rotational grazing (Hunt 1989) and pastures remain relatively low in tiller and plant density. More frequent and lenient defoliation as experienced under set stocking, while restricting organ size, enhances tiller and stolon survival and increases pasture density. These effects are more important to the dominant grass component, where severity of defoliation is directly proportional to the area of the vertically arranged leaves removed. With white clover where fully expanded leaves are elevated into the upper canopy, severity of grazing is less important, as virtually all fully expanded lamina are removed early. Expression of white clover growth potential then, is controlled largely by defoliation frequency as described by Brougham (1958) and Carlson (1966). Following defoliation, the first new leaf produced is small, with successive leaves increasing in size. Under infrequent defoliation, such as rotational grazing, several leaves can be produced, allowing greater development of individual leaf area, and consequently, stolon diameter and internode length. Increasing the frequency of defoliation decreases the time available for full expression of leaf area, and the leaf size attained is reduced and a new equilibrium is established. With set stocking, defoliation frequency rarely allows more than one fully expanded leaf to develop per stolon before defoliation, and the equilibrium between defoliation frequency and area/ leaf is set at a low level. As a consequence, although structurally similar, rotationally grazed plants can be 2-3 times heavier than those under set stocking (Brock 
et al. 1988). Variation in this size/density compensation in response to grazing management, is a fundamental characteristic that distinguishes the relative performance of the available white clover cultivars.

\section{White clover cultivars}

With the upper limit to potential white clover growth constrained ecologically (soil fertility and $\mathrm{N}$ status, animal behaviour, etc.), the role of white clover improvement programmes is largely aimed at producing more competitive cultivars, in order to maximise their opportunity to gain a greater share of the restricted resources available, thereby increasing potential herbage production. As a consequence, in order to demonstrate maximum genetic potential, emphasis has been placed on selecting under 'ideal' conditions of long regrowth. Increases in growth potential achieved since selection of white clover began in New Zealand is in the order of 65\% (Caradus et al. 1996a), and now, an extensive range of new cultivars covering the wide range of morphological variation with improved potential for various livestock systems are available (Caradus et al. 1996b).

\section{Grazing management by cultivar interactions}

Discussion of plant growth and population stability so far would suggest that grazing management may not be of great importance for the survival and production of white clover, if a cultivar has sufficient phenotypic plasticity to adapt to prevailing conditions. However, this is not the case, as the degree of size/density compensation required is not always attainable. While many of the more recent cultivars are too new to have had extensive evaluation, a study of earlier cultivars covering the range of morphology will serve to illustrate the occurrence of a grazing management by cultivar performance interaction.

By way of example, a comparison of the performance of Tahora, Huia, Pitau and Kopu in mixed pastures under rotational grazing and set stocking at high stocking rate by sheep over five years, illustrates the trade-off of production and persistence through phenotypic plasticity (Table 1). Under rotational grazing where greatest expression of growth potential should occur, all cultivars performed equally well overall (leaf DW), with the advantage of the greater allocation of growth to leaf (leaf/stolon ratio) and the larger leaves (area/leaf) produced by Pitau and Kopu, compensated by the higher branching and growing point density of the smaller leaved cultivars Tahora and Huia. With the frequent defoliation of set stocking (approx. every 10-12 days), the positions were reversed. As a result of reduced leaf size, which could not be countered by the necessary increase in growing point density, the performance of the large-leaved cultivars (including Huia) fell. Only Tahora by greatly increasing growing point density was able to increase production.

This example demonstrates two main points: (1) that under set stocking, small-leaved cultivars, such as Tahora, will be clearly superior (and even more clear is that large-leaved cultivars are totally unsuitable), and (2) the superiority of large-leaved cultivars such as Kopu under rotational grazing, cannot be taken for granted in the long-term, at least with sheep. Based on long experience with Huia white clover, the general perception has been that white clover production is greater with cattle than sheep. This may still be the case, and with cattle grazing, the results illustrated above, may show large-leaved cultivars such as Kopu, to improve their relative superiority over the smallleaved cultivars. Nevertheless, the level of size/density compensation that some of the newer small-leaved, high density cultivars are capable of, may still reduce differences more than expected. In general, the model of higher density branching adopted for some recent lowland cultivars to maintain productivity through a greater density of smaller leaves should improve persistency considerably.

Table 1: Mean performance of four white clover cultivars over five years under rotational grazing and set stocking with sheep at Palmerston North.

\begin{tabular}{|c|c|c|c|c|c|c|c|c|}
\hline & \multicolumn{4}{|c|}{ 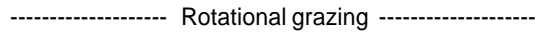 } & \multicolumn{4}{|c|}{ 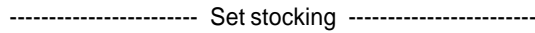 } \\
\hline & Tahora & Huia & Pitau & Kopu & Tahora & Huia & Pitau & Kopu \\
\hline Area/leaf $\left(\mathrm{cm}^{2}\right)$ & $1.27 \mathrm{~cd}^{*}$ & $1.60 \mathrm{c}$ & $2.54 b$ & $3.05 a$ & $0.51 f$ & $0.76 \mathrm{ef}$ & $0.88 \mathrm{ef}$ & $1.00 \mathrm{de}$ \\
\hline Leaves $\left(\mathrm{m}^{2}\right)$ & 7320b & $4360 \mathrm{c}$ & $4210 \mathrm{c}$ & $3390 \mathrm{c}$ & 19270a & $7480 \mathrm{~b}$ & $4140 \mathrm{~cd}$ & 3610de \\
\hline Growing points $\left(\mathrm{m}^{2}\right)$ & $3040 \mathrm{bc}$ & 1810de & 1820de & $1400 \mathrm{e}$ & $11000 \mathrm{a}$ & $3650 b$ & $2470 \mathrm{~cd}$ & $2140 \mathrm{de}$ \\
\hline Leaf DW $\left(\mathrm{g} / \mathrm{m}^{2}\right)$ & $30.9 b$ & $25.0 \mathrm{bc}$ & $28.6 b c$ & $30.9 b$ & $46.1 \mathrm{a}$ & $19.0 \mathrm{~cd}$ & $11.1 d$ & $11.6 d$ \\
\hline LAI & $0.84 a b$ & $0.71 \mathrm{bc}$ & $0.98 \mathrm{a}$ & $1.00 \mathrm{a}$ & $0.92 a b$ & $0.54 \mathrm{c}$ & $0.31 \mathrm{c}$ & $0.35 \mathrm{c}$ \\
\hline Stolon DW $\left(\mathrm{g} / \mathrm{m}^{2}\right)$ & $34.5 b$ & $24.6 \mathrm{~cd}$ & $26.2 \mathrm{c}$ & $24.2 \mathrm{~cd}$ & $69.4 a$ & $30.2 b c$ & $18.1 d$ & $17.8 d$ \\
\hline Leaf:Stolon ratio & $0.97 \mathrm{~b}$ & $1.03 b$ & $1.16 a b$ & $1.33 a$ & $0.68 \mathrm{c}$ & $0.64 \mathrm{c}$ & $0.66 \mathrm{c}$ & $0.67 \mathrm{c}$ \\
\hline
\end{tabular}

* values followed by different letters within rows, are significantly different at $\mathrm{P}<0.05$ level 


\section{The effect of companion grasses}

In practice, defoliation management is designed around the needs of the dominant grass component, where the greatest size/density compensation (plasticity) takes place, with important consequences for the pasture as a whole, including white clover. It is fortunate for white clover that the most common companion grass is perennial ryegrass, a species exhibiting a similar degree of plasticity to white clover in its ability to accommodate a wide range of defoliation managements. This allows a flexibility that may be manipulated to the advantage of white clover. Being a highly mobile opportunist species, white clover requires space in order to fully develop. For instance, Brereton et al. (1985) found that at densities below 5000 ryegrass tillers $/ \mathrm{m}^{2}$, there was little competition on white clover and was able to maintain a higher content in pasture. At greater grass densities, competition for space progressively increased and white clover herbage content decreased. Hence rotationally grazed pastures encourage greater white clover growth, particularly the larger-leaved cultivars able to elevate their leaves to compete for light in the taller pastures. As increasing defoliation frequency increases grass tiller density and lowers canopy height, competition for space shifts the balance towards cultivars with smaller leaves or a high degree of phenotypic plasticity, usually associated with higher branching density.

\section{Climate interactions}

Ryegrass/white clover associations perform best in cooltemperate climates, without environmental extremes in rainfall and temperature. Under average conditions all white clover cultivars will perform as well as the prevailing cultural environment will allow as outlined above. White clover is difficult to maintain in dryland situations, and has generated considerable research into drought tolerance. When drought occurs the effects on white clover performance can be dramatic. While definitive research on the effects of drought on white clover in the field are scarce, interpretation of what is available along with observation suggests summerautumn droughts are generally less severe on white clover than earlier spring-summer droughts. It may be that plant populations recovering from spring fragmentation may be more susceptible to stress at that time. For example, a dryland Canterbury study found summer drought in one year reduced white clover content by $30 \%$, whereas in the second year, spring drought (October) combined with autumn drought separated by good summer rain, resulted in a 50\% reduction in white clover content (Vartha \& Hoglund 1983). Grazing management in spring has a major influence on drought severity and recovery. In the cultivar comparison experiment discussed above, one severe late spring drought in the second summer, reduced white clover stolon by $85-90 \%$ only in those treatments rotationally grazed through the spring (Brock 1988). Treatments set stocked through the spring did not suffer any white clover stolon loss. All cultivars behaved similarly. The key was the grass density, where the dense pastures created by set stocking (11-15000 tillers $/ \mathrm{m}^{2}$ ) provided full cover and shaded white clover stolons from direct solar radiation, compared to the low density, open rotationally grazed pastures $\left(5-6000\right.$ tillers $\left./ \mathrm{m}^{2}\right)$ with large areas of bare ground. Mean peak soil surface daytime temperatures were $8^{\circ} \mathrm{C}$ cooler under set stocked pastures than rotationally grazed $\left(40^{\circ} \mathrm{C}\right.$ vs $\left.48^{\circ} \mathrm{C}\right)($ Brock $\&$ Hay 1993). As a consequence of this differential loss of stolon between managements, recovery of white clover following rain was immediate under set stocking, but took one to three years under rotational grazing, with small-leaved Tahora recovering faster than the largeleaved Pitau and Kopu (Brock \& Caradus 1996). Further experimentation (Brock \& Kim 1994) confirmed that protection at the soil surface by shading (and to a lesser extent stolon burial) was an important factor in survival under extreme drought, but also showed that the predrought structure of the plants (number or orders of branches) had no effect, and plants died back to individual rooted nodes. Cultivars with high node density initiated new root and shoot formation more rapidly, and had a greater survival rate, than cultivars with low node density. Hence the quicker recovery of Tahora relative to Pitau and Kopu (Brock \& Caradus 1996)

This discussion suggests that there is little in the plant growth processes and population structure per se, of white clover, that is critical in drought survival of white clover, including the period of plant fragmentation in spring, although there is evidence that fragmentation is less under set stocking than rotational grazing (Hay et al. 1988; Brock unpub. data). Instead, it is apparent that the major effects of a defoliation system on white clover survival and performance, operate indirectly through the grass component in determining the quality of the environment for white clover growth.

\section{Pasture management}

\section{Grass growth processes}

Studies of ryegrass, tall fescue and cocksfoot (Brock \& Fletcher 1993; Brock et al. 1995) have shown that these grasses grow by essentially the same clonal processes as white clover, with fragmentation resulting in plant structure (leaf and branch numbers) and population distribution between branching hierarchies very similar to white clover. Mean plant DW of ryegrass is often smaller than white clover, and exhibit a similar plasticity 
in response to changes in grazing management. The chief difference is that lateral spread is restricted by the vertical orientation of the stems and tillers to form an upright tufted habit. As fragmentation occurs, these tufts increase in diameter, and consist of large numbers of small plants in close proximity (Brock \& Thomas 1991), providing mutual support and protection for each other, neighbouring tufts and other species, crucial to species and pasture performance and survival, particularly when under extremes of stress as outlined above.

As a result of these clonal growth processes, grasses also have a critical period of vulnerability during flowering in late spring/early summer. Reproductive tillers lost by flowering, are replaced by daughter tillers, but these will survive only if the emerging flower head is removed before full emergence in order to divert resources otherwise destined for reproductive growth to the establishment of the daughter tillers thus maintaining tiller density (Matthew et al. 1989; 1991). Timing of the removal of flower heads by grazing is difficult to achieve under rotational grazing. Set stocking avoids the problem by continual removal of flower heads as they appear thus maintaining a high tiller density.

\section{Grazing management systems}

Grazing management of mixed species in pasture presents a conflict of interests. Productivity is theoretically enhanced by providing a pasture structure with a higher harvest index such as is accomplished by rotational grazing. The reduced grass tiller density will allow more space for the expression of white clover growth, provided grass competition can be controlled. This must be balanced against the greater vulnerability of low density pastures to adverse conditions that could reduce persistence. Set stocking clearly has the converse effect, increasing pasture density and hence persistence, but at the expense of individual growth unit potential.

The most critical period for pasture management is in the mid-spring to early summer, the time of maximum growth when conditions are most favourable. Because of natural processes in their life cycles, both grass and white clover populations are less stable and vulnerable to stress. Grazing management should be aimed at reducing physiological and environmental stress and aiding plant survival. This can best be achieved through increasing defoliation frequency by maintaining good control of pasture with short rotation lengths (Brougham 1960) or set stocking during the spring-early summer (Brock 1988). This may reduce potential yield at the time, but the increase in the density of both grass and white clover can be capitalised on if followed by rotational grazing to exploit the genetic potential of the species/cultivars over the remainder of the year. Research has shown that in this way, with careful choice of cultivars of both grass and white clover for the conditions to ensure maximum productivity, high productivity can be maintained with marked resistance to adverse conditions and enhanced species survival and persistence (Brock 1988; Brock \& Hay 1993).

These principles have been utilised in different ways. The practice of heavy set stocking in spring to increase white clover growing point density to produce white clover dominance in summer with a change to rotational grazing has been promoted for lamb fattening in Southland (Hay \& Baxter 1989). Similarly, 5-day rotations produced denser pastures with more white clover compared to 20-day rotations without penalising milk production from dairy cows at Ruakura (Thom \& Bryant 1993).

\section{References}

Ball, P.R. 1982. Nitrogen balances in intensively managed pasture systems. pp. 47-66. In: Gandar, P.W. (ed.). Nitrogen balances in New Zealand ecosystems. DSIR, New Zealand.

Brereton, A.J.; Carton, O.T.; Conway, A. 1985. The effect of grass tiller density on the performance of white clover. Proceedings International Grassland Congress 15: 756-757.

Brock, J.L. 1988. Evaluation of New Zealand bred white clover cultivars under rotational grazing and set stocking with sheep. Proceedings of the New Zealand Grassland Association 49: 203-206.

Brock, J.L. 1991. The pasture ryegrass plant, what is it? Proceedings of the New Zealand Grassland Association 53: 111-116.

Brock, J.L.; Caradus, J.R.; Hay, M.J.M. 1989. Fifty years of white clover research in New Zealand. Proceedings of the New Zealand Grassland Association 50: 25-39.

Brock, J.L.; Hay, M.J.M.; Thomas, V.J.; Sedcole, J.R. 1988. Morphology of white clover (Trifolium repens L.) plants in pastures under intensive sheep grazing. Journal of Agricultural Science, Cambridge, 111: 273-283.

Brock, J.L.; Fletcher, R.H. 1993. Morphology of perennial ryegrass (Lolium perenne) plants in pastures under intensive sheep grazing. Journal of Agricultural Science, Cambridge, 120: 301-310.

Brock, J.L.; Hay, R.J.M. 1993. An ecological approach to forage management. Proceedings International Grassland Congress 17: 837-842.

Brock, J.L.; Moon Chul Kim. 1994. Influence of the stolon/soil surface interface and plant morphology on the survival of white clover during severe drought 
stress. Proceedings of the New Zealand Grassland Association 56: 187-191.

Brock, J.L.; Hume, D.E.; Fletcher, R.H. 1995. Seasonal variation in the performance of perennial ryegrass (Lolium perenne) and cocksfoot (Dactylis glomerata) plants and populations in pastures under intensive sheep grazing. Journal of Agricultural Science, Cambridge (in press).

Brock, J.L.; Caradus, J.R. 1996. Influence of grazing management and drought on white clover population performance and genotypic frequency. Agronomy Society of New Zealand Special Publication No. 11/ Grassland Research and Practice Series No. 6: 7982.

Brougham, R.W. 1958. Leaf development in swards of white clover (Trifolium repens L.). New Zealand Journal of Agricultural Research 1: 707-718.

Brougham, R.W. 1960. The effect of frequent hard grazing at different times of the year on the productivity and species yield of a grass-clover pasture. New Zealand Journal of Agricultural Research 3: 125-136.

Caradus, J.R.; Woodfield, D.R.; Stewart, A.V. 1996a. Overview and vision for white clover. Agronomy Society of New Zealand Special Publication No. 11/ Grassland Research and Practice Series No. 6: 1-6.

Caradus, J.R.; Hay, R.J.M.; Woodfield, D.R. 1996b. The positioning of white clover cultivars in New Zealand. Agronomy Society of New Zealand Special Publication No. 11/Grassland Research and Practice Series No. 6: 45-50.

Carlson, G.E. 1966. Growth of white clover leaves after leaf removal. Proceedings International Grassland Congress 10: 134-139.

Field, T.R.O.; Ball, P.R. 1982. Nitrogen balance in an intensively utilised dairy farm system. Proceedings of the New Zealand Grassland Association 43: 6469.

Hay, M.J.M.; Brock, J.L.; Fletcher, R.H. 1983. Effect of sheep grazing management on distribution of white clover stolons among 3 horizontal strata in ryegrass/white clover swards. New Zealand Journal of Experimental Agriculture 11: 215-218.

Hay, R.J.M.; Baxter, G.S. 1989. Manipulating the plastic response of white clover through grazing, in a cool, temperate climate in New Zealand. Proceedings International Grassland Congress 16: 1053-1054.

Hay, M.J.M.; Chapman, D.F.; Hay, R.J.M.; Pennell, C.G.L.; Woods, P.W.; Fletcher, R.H. 1987. Seasonal variation in the vertical distribution of white clover stolons in grazed swards. New Zealand Journal of Agricultural Research 30: 1-8.

Hay, M.J.M.; Brock, J.L.; Thomas, V.J.; Knighton, M.V. 1988. Seasonal and sheep grazing management effects on branching structure and dry weight of white clover plants in mixed swards. Proceedings of the New Zealand Grassland Association 49: 197-201.

Hay, M.J.M.; Brock, J.L.; Thomas, V.J. 1989. Density of Trifolium repens plants in mixed swards under intensive sheep grazing. Journal of Agricultural Science, Cambridge, 113: 81-86.

Hoglund, J.H.; Brock, J.L. 1987. Nitrogen fixation in managed grasslands. pp. 187-196. In: Snaydon, R.W. (ed.). Managed Grasslands: Analytical Studies. Ecosystems of the World 17B. Elsevier Science Publications B.V., Amsterdam.

Hollowell, E.A. 1966. White clover Trifolium repens L., annual or perennial? Proceedings International Grassland Congress 10: 184-187.

Hunt, W.F. 1989. Grazing management effects on perennial ryegrass and white clover tillers populations. Proceedings International Grassland Congress 16: 1055-1056.

Kershaw, K.A. 1959. An investigation of the structure of a grassland community II. The pattern of Dactylis glomerata, Lolium perenne and Trifolium repens. Journal of Ecology 47: 31-43.

Matthew, C.; Quilter, S.J.; Korte, C.J.; Chu, A.C.P.; MacKay, A.D. 1989. Stolon formation and significance for sward tiller dynamics in perennial ryegrass. Proceedings of the New Zealand Grassland Association 50: 255-259.

Matthew, C.; Chu, A.C.P.; Hodgson, J.; MacKay, A.D. 1991. Early summer pasture control: what suits the plant? Proceedings of the New Zealand Grassland Association 53: 73-79.

Suckling, F.E.T.; Forde, M. 1978. Genetic resources in high rainfall pastures of New Zealand. I. Collection of ryegrass, browntop and white clover. New Zealand Journal of Agricultural Research 21: 499-508.

Thom, E.R.; Bryant, A.M. 1993. Effects of different systems of grazing management during December to May on the grass tiller density characteristics of ryegrass/white clover dairy pasture. Proceedings International Grassland Congress 17: 877-878.

Ulyatt, M.J. 1985 Pasture composition and animal production. pp. 195-203. In: Baker, S.K.; Gainthorne, J.M.; Purser, D.B. (eds). Ruminant physiology: Concepts and consequences. University of Western Australia, Perth.

Vartha, E.W.; Hoglund, J.H. 1983. What is the make up of a dryland pasture? Proceedings of the New Zealand Grassland Association 44: 204-210.

Williams, W.M.; Lambert, M.G.; Caradus, J.R. 1982. Performance of a hill country white clover selection. Proceedings of the New Zealand Grassland Association 43: 188-195. 